\title{
Evaluation of skin autofluorescence as a surrogate of advanced glycation end products accumulation in children and adolescents with normal haemoglobin $\mathrm{A}_{1 \mathrm{c}}$ values
}

Ocena autofluorescencji skóry jako miary akumulacji zaawansowanych produktów końcowej glikacji u dzieci i młodzieży z prawidłowym stężeniem hemoglobiny $\mathrm{A}_{1 \mathrm{c}}$

\author{
${ }^{1}$ Marta Jankowska, ${ }^{2}$ Katarzyna Bobeff, ${ }^{3}$ Anna Baranowska-Jaźwiecka, ${ }^{4}$ Maria Mianowska, \\ ${ }^{4}$ Anna Lubnauer, ${ }^{3}$ Arkadiusz Michalak, ${ }^{2}$ Wojciech Młynarski, ${ }^{3}$ Agnieszka Szadkowska, \\ ${ }^{3}$ Beata Mianowska
}

\begin{abstract}
${ }^{1}$ University Paediatric Centre of the Central Teachning Hospital, Medical University of Lodz, Poland ${ }^{2}$ Department of Paediatrics, Oncology, and Haematology, Medical University of Lodz, Poland ${ }^{3}$ Department of Paediatrics, Diabetology, Endocrinology, and Nephrology, Medical University of Lodz, Poland ${ }^{4}$ Student's Scientific Circle at the Department of Paediatrics, Diabetology, Endocrinology, and Nephrology and Department of Paediatrics, Oncology, and Haematology, Medical University of Lodz, Poland
\end{abstract}

\begin{abstract}
Introduction: Skin autofluorescence (SAF) represents tissue accumulation of advanced glycation end products (AGEs) and correlates with cardiovascular morbidity and diabetes risk.

The aim: To assess sAF in Polish children without diabetes and to investigate whether sAF values in children with chronic diseases (but without glucose metabolism disorders) differ from sAF in healthy children.

Material and methods: Children without diseases known to influence sAF results (diabetes, renal failure) and with $\mathrm{HbA}_{1 \mathrm{c}}<5.7 \%$ (39 $\mathrm{mmol} / \mathrm{mol}$ ) were included, and the total study group was divided into two subgroups: with and without chronic conditions. Skin autofluorescence was measured with an AGE Reader (Diagnoptics BV, Groningen, Netherlands). Data were presented as medians; Mann-Whitney U-test, Kruskall Wallis test, and Spearman's correlation coefficients were used in statistical analyses.

Results: The study group included 86 children (41 girls; mean age $10.1 \pm 4.2$ years). Median sAF was 1.20 AU (25 $5^{\text {th }}-75^{\text {th }}$ centile: 1.06-1.30). There was a positive correlation between $s A F$ and age $(R=0.37, p=0.0005)$. Skin autofluorescence values were higher in children with chronic diseases than in healthy children (1.23 AU [25 $5^{\text {th }}-75^{\text {th }}$ centile: $\left.1.10-1.40\right], n=51$ vs. 1.16 AU [1.06-1.26], $n=36, p=0.0272)$.

Conclusions: To our knowledge we present the first data on SAF values in Polish children without glucose metabolism disorders. We suggest that larger, homogenous populations of different ages should be studied to determine if and which diseases affect sAF measurements, and to develop pediatric reference values for sAF. This will allow a wider use of sAF measurement in the assessment of cardiovascular risk in the paediatric population.

Key words: skin autofluorescence, advanced glycation end products (AGEs), glycated haemoglobin $\mathrm{A}_{1 \mathrm{c}}\left(\mathrm{HbA}_{1 \mathrm{c}}\right.$ ), AGE Reader, children.
\end{abstract}

\section{Streszczenie}

Wprowadzenie: Autofluorescencja skóry (skin autofluorescence - sAF) odzwierciedla zawartość końcowych produktów zaawansowanej glikacji (advanced glycation end products - AGEs) w organizmie i wyniki jej pomiaru korelują z obecnością i nasileniem zaburzeń metabolizmu glukozy i z występowaniem chorób sercowo-naczyniowych.

Cel pracy: Ocena sAF u polskich dzieci oraz zbadanie, czy wartości sAF u dzieci z chorobami przewlekłymi (ale bez zaburzeń metabolizmu glukozy) różnią się od wartości sAF u dzieci zdrowych.

Materiał i metody: Badaniami objęto dzieci z prawidłowym stężeniem hemoglobiny glikowanej [ $\left.\mathrm{HbA}_{1 \mathrm{c}}<5,7 \%(39 \mathrm{mmol} / \mathrm{mol})\right]$. Grupę badaną podzielono na dwie podgrupy: dzieci z chorobami przewlekłymi (z wykluczeniem chorób o znanym wpływie na sAF cukrzyca, niewydolność nerek) oraz dzieci zdrowych. Pomiar sAF wykonywano w sposób nieinwazyjny, za pomocą urządzenia AGE Reader (Diagnoptics BV, Groningen, Holandia). Wyniki przedstawiono jako mediany; w analizie statystycznej wykorzystano test U Manna-Whitneya, test Kruskalla Wallisa oraz współczynniki korelacji Spearmana. 
Wyniki: Grupę badaną stanowiło 86 dzieci (41 dziewczynek i 45 chłopców; średni wiek 10,1 $\pm 4,2$ roku) - 36 dzieci zdrowych i 51 ze schorzeniami przewlekłymi (u większości rozpoznano choroby alergiczne, choroby krwi, choroby tarczycy). Mediana sAF wynosiła 1,20 AU (25.-75. centyl: 1,06-1,30). Stwierdzono dodatnią korelację między sAF a wiekiem $(R=0,37, p=0,0005)$. Wartości sAF były wyższe u dzieci z chorobami przewlekłymi niż u dzieci zdrowych $[1,23$ AU (25.-75. centyl: 1,10-1,40) vs 1,16 AU $(1,06-1,26) p=0,0272]$.

Wnioski: Zgodnie z wiedzą autorów jest to pierwsze podsumowanie prezentujące wartości sAF u polskich dzieci w różnym wieku, bez zaburzeń metabolizmu glukozy. Wskazane są dalsze badania obejmujące większe, jednorodne populacje, które pozwolą ocenić, czy i jakie choroby wpływają na wyniki pomiaru sAF i umożliwią opracowanie wartości referencyjnych sAF dla polskiej populacji pediatrycznej. Pozwoli to na szersze zastosowanie pomiarów sAF w ocenie ryzyka sercowo-naczyniowego u dzieci.

\section{Słowa kluczowe:}

autofluorescencja skóry, końcowe produkty zaawansowanej glikacji (AGEs), hemoglobina glikowana $A_{1 c}\left(H_{b A}\right)$, AGE Reader, dzieci.

\section{Introduction}

Advanced glycation end products (AGEs) are a group of heterogenous cross-link compounds formed in human tissues. The initial, reversible step of their formation is spontaneous glycation of amino groups mainly on lysine amino residues of tissue proteins. The extent of this nonenzymatic glycosylation depends on the ambient glucose concentration in the tissue environment. The major product of this initial process (Amadori reaction) is fructose lysine, a ketoamine from which in subsequent, irreversible Maillard (so-called browning) reaction of oxidative cleavage $\mathrm{N}$-(carboxymethyl)lysine $(\mathrm{CML})$ is formed. Examples of other products of Maillard reaction (i.e. AGEs) in human tissues are $\mathrm{N}$-(carboxymethyl)hydroxylysine (CMhL) (from glycated hydroxylysine) or pentosidine. The latter is a fluorescent compound formed as a crosslink between arginine and lysine residues $[1,2]$. CML, CMhL, and pentosidine have been termed "glycoxidation products" because both glycation and free radical oxidation reactions are necessary for their formation from reducing sugars, and oxidative stress may also promote AGEs formation [1, 2]. Moreover AGEs accumulation in tissue specimens correlated with intensity of inflammatory cell deposition because, through AGE receptors (RAGE), AGEs induce inflammation [3]. According to the "glycation hypothesis", which explains aging and development of diabetes complications, accumulation of AGEs alters the structure and properties of proteins in different tissues (e.g. collagen in skin) and reduces their susceptibility to catabolism [1].

The fluorescent property of some of AGEs, like pentosidine, was used in a device designed for noninvasive measurement of skin autofluorescence (AGE Reader, Groningen, Netherlands). Results of skin autofluorescence (SAF) measurements performed with an AGE Reader have been shown to correlate strongly with tissue accumulation of AGEs in patients with diabetes and in subjects without chronic diseases [3, 4].

The AGEs content measured in the human body as SAF is influenced by age and lifestyle, being higher in older compared to younger persons, in smokers than in non-smokers, and in physically inactive compared to physically active people [5-7]. In adults it was also shown that higher SAF values correlated with the severity or presence of some chronic conditions: with cardio- vascular diseases, with higher glycated haemoglobin concentration and the presence of chronic complications in persons with diabetes, with the severity of renal failure, with osteoporosis, with Alzheimer's disease, and with some neoplastic diseases [8-14].

Because sAF values correlate with cardiovascular morbidity, diabetes risk, and with cardiovascular and all-cause mortality $[8,15,16]$, it was proposed that sAF can be used as an additional marker in models assessing cardiovascular and diabetes risk, improving the reliability of such risk scores $[17,18]$. Results of SAF values obtained for persons of similar age but from various countries were different, and to enable proper interpretation of SAF measurements in the context of assessment of health hazards, reference values for SAF for several populations have been published $[5,6]$. Because no results of sAF assessment for the Polish paediatric population have been published so far, the aim of this study was to assess sAF in a sample of Polish children and adolescents without glucose metabolism disorders, and to investigate whether sAF values in children with chronic diseases (but without glucose metabolism disorders) differ from SAF in the group of healthy children.

\section{Material and methods}

It was a cross-sectional study including consecutive children referred for routine laboratory tests at Maria Konopnicka's Paediatric University Centre in Lodz, Poland. Inclusion criteria were age from 2 to 18 years and parents' or caregivers' written, informed consent for the child's participation in the study; participants aged 16 years and more additionally signed the written, informed consent by themselves. Exclusion criteria were as follows: diagnosis of diabetes, renal failure, overt cardiovascular disease, signs or symptoms of any acute illness at the time of examination, symptoms characteristic for diabetes at the time of examination, and parents'/guardians' or child's nonagreement for participation in the study. To exclude glucose metabolism disordershemoglobin $\mathrm{A}_{1 \mathrm{c}}\left(\mathrm{HbA}_{1 \mathrm{c}}\right)$ was measured and participants with $\mathrm{HbA}_{1 \mathrm{c}}$ concentration $\geq 5.7 \%$ (39 $\left.\mathrm{mmol} / \mathrm{mol}\right)$, i.e. fulfilling $\mathrm{HbA}_{1 \mathrm{c}}$ based criterion defining prediabetes according to the American Diabetes Association [19], were excluded from the final analyses. 
Participants' medical history, including chronic diseases and medication, was obtained during an interview with their parents, and data regarding weight and height were collected. Body mass index standard deviation scores (BMI-SDS) were calculated based on local growth charts.

Skin autofluorescence (SAF) was measured with an AGE Reader mu (Diagnoptics BV, Groningen, Netherlands), making sure that the tested skin area was clean. The whole sAF assessment lasts about 2-4 minutes. The patient places the volar side of the forearm of the dominant limb on the base of the device, which for several seconds illuminates approximately $4 \mathrm{~cm}^{2}$ of the skin with light of wavelength $300-420 \mathrm{~nm}$. The sAF measurement result is calculated by the device as the ratio of the intensity of the emitted light (420-600 nm; total emission intensity) to the excitation intensity (300-420 nm) multiplied by 100 and given in arbitrary units (AU). Three independent measurements were performed for each patient with approximately 30 -s intervals, and the average of three values was used as the final result.

Capillary blood samples were collected for assessment of $\mathrm{HbA}_{1 \mathrm{c}}$ concentration. $\mathrm{HbA}_{1 \mathrm{c}}$ levels were determined by highperformance liquid chromatography (HPLC) using D-10 Hemoglobin $A_{1 c}$ Program (Bio-Rad Laboratories, Hercules, CA, BioRad, Marnes-la-Coquette, France); local mean $\mathrm{HbA}_{1 \mathrm{c}}$ and 95\% confidence interval $(95 \% \mathrm{Cl})$ for subjects without diabetes: $5.12 \%$ (95\% Cl: $4.50-5.75 \%)$ (32 mmol/mol\% [95\% Cl: 26-39 $\mathrm{mmol} / \mathrm{mol}])$.

The study was approved by the Bioethics Committee of the Medical University of Lodz - RNN/49/18/KE and RNN/116/18/ $\mathrm{KE}$ with a resolution amending the Bioethics Committee of the European Commission/554/18.

\section{Statistical analysis}

Due to skewed distribution of variables, data are presented as median and interquartile range, and groups were compared using Mann-Whitney U-test or Kruskall-Wallis test with post-hoc analyses. Spearman's correlation coefficients were calculated to test correlations. A general linear model was used to investigate the effect of independent variables on skin autofluorescence levels. $P$ values $<0.05$ were considered significant. The Statistica 13 software package (software.dell.com) was used for statistical analyses.

\section{Results}

A total of 98 children were offered participation in the study. Parents of seven children did not agree to participate. Five participants initially qualified for the study were excluded from the analysis due to $\mathrm{HbA}_{1 \mathrm{c}}$ concentration $\geq 5.7 \%$ (39 mmol/mol). The final study group included 86 Caucasian children (41 girls and 45 boys; mean age 10,1 \pm 4.2 years), of whom 36 were healthy children and 51 were children with different chronic conditions. Characteristics of the study group are presented in Table I, II, and III. Median of age and BMI-SDS were similar in participants with chronic diseases and in children without chronic diseases, while $\mathrm{HbA}_{1 \mathrm{c}}$ concentration was lower in participants with chronic diseases (Table IV).

Values of SAF ranged from 0.9 to $2.5 \mathrm{AU}$, median 1.20 AU (25 $-75^{\text {th }}$ centile: $1.06-1.30$, Table I); SAF did not differ between boys and girls (Table III). The highest sAF (2.5 AU) was detected in a 17-year-old boy with $\mathrm{HbA}_{1 \mathrm{c}} 5.0 \%$ (31 mmol/mol) with a history of acute pancreatitis and laboratory features of hepatitis at the time of the examination, who was not taking any medication at the time of the study, and the second highest SAF (1.8 AU) was measured in a 14.5-year-old girl ( $\mathrm{HbA}_{10}$ $4.9 \%$ [30 mmol/mol]) with von Willebrand disease taking tranexamic acid and cyclonamine. The lowest SAF values of $0.9 \mathrm{AU}$ were detected in two boys, a three-year-old $\left(\mathrm{HbA}_{1 \mathrm{c}} 4.9 \%\right.$ [30 mmol/mol]) with thrombocytopaenia and a 12-year-old $\left(\mathrm{HbA}_{1 \mathrm{c}} 5.3 \%\right.$ [34 mmol/mol]) without any chronic diseases; none of them was taking any medication.

There was a positive correlation between SAF value and age $(R=0.37, p=0.0005)$. Values of $\mathrm{SAF}$ for all participants

Table I. Characteristics of the study group $(n=86)$

\begin{tabular}{llllll}
\hline Characteristics & Median & $25^{\text {th }}$ centile & $75^{\text {th }}$ centile & Minimum & Maximum \\
\hline Age [years] & 11.40 & 8.02 & 14.23 & 2.24 & 17.99 \\
\hline BMl SDS & 0.05 & -0.24 & 0.72 & -3.55 & 2.29 \\
\hline $\mathrm{HbA}_{1 \mathrm{c}}[\%]$ & 5.10 & 4.90 & 5.20 & 3.50 & 5.60 \\
\hline $\mathrm{HbA}{ }_{1 \mathrm{C}}[\mathrm{mmol} / \mathrm{mol}]$ & 32 & 30 & 33 & 15 & 38 \\
\hline $\mathrm{SAF}[\mathrm{AU}]$ & 1.20 & 1.06 & 1.30 & 0.90 & 2.50 \\
\hline
\end{tabular}

BMI-SDS - standard deviation score of $\mathrm{BMl} ; \mathrm{HbA}_{10}$ - glycated hemoglobin $\mathrm{A}_{10}$; sAF - skin autofluorescence expressed in arbitrary units [AU] 
Table II. Characteristics of participants with chronic conditions $(n=51)$ - diagnosis (4 persons had 2 diagnoses) and medication

\begin{tabular}{|c|c|c|c|}
\hline Diagnosis & $\begin{array}{l}\text { Number } \\
\text { of subjects } \\
\text { with particular } \\
\text { diagnosis }\end{array}$ & Medication & $\begin{array}{l}\text { Number } \\
\text { of subjects } \\
\text { taking particular } \\
\text { medication }\end{array}$ \\
\hline \multicolumn{4}{|c|}{ Allergic disorders } \\
\hline $\begin{array}{l}\text { Allergic disorders including asthma, } \\
\text { atopic dermatitis, food allergy }\end{array}$ & 18 & $\begin{array}{l}\text { Desloratadine, loratadine, cetirizine, } \\
\text { montelucast, rupatadine, almeterol, } \\
\text { budesonide/formoterol (inhalation) }\end{array}$ & 12 \\
\hline \multicolumn{4}{|c|}{ Disorders of the thyroid gland } \\
\hline Autoimmune thyroiditis & 3 & Levothyroxine & 1 \\
\hline Hyperthyroidism & 1 & Thiamazole & 1 \\
\hline \multicolumn{4}{|c|}{ Diseases of the blood } \\
\hline Anemia (hemolytic, syderopenic) & 7 & Iron products, pyridoxine, folic acid & 3 \\
\hline Thrombocytopenia & 8 & Cyclonamine & 3 \\
\hline Leucopenia (inc. neutroopenia) & 6 & - & - \\
\hline von Willebrand disease & 1 & Tranexamic acid, etamsylate & 1 \\
\hline \multicolumn{4}{|c|}{ Disorders of the digestive system } \\
\hline $\begin{array}{l}\text { Acute pancreatitis (in the history), } \\
\text { hepatitis (present) }\end{array}$ & 1 & - & - \\
\hline Cholelythiasis & 1 & Ursodeoxycholic acid & 1 \\
\hline \multicolumn{4}{|c|}{ Other disorders } \\
\hline Epilepsy & 4 & Valproate sodium, ethosuximidum & 4 \\
\hline Depression & 1 & Fluoxetine & 1 \\
\hline Hearing loss & 1 & - & - \\
\hline Nephrotic syndrome & 1 & Ciclosporin & 1 \\
\hline Hypoplastic kidney & 1 & - & - \\
\hline Lymphedema & 1 & - & \\
\hline Prophylactic/supplementary medication & 0 & Phospholipids, colecalciferol & 2 \\
\hline
\end{tabular}

stratified according to age categories are presented in Figure 1. There were no significant correlations between SAF and BMI-SDS $(R=0.16, p=0.1504)$, nor between SAF and $\mathrm{HbA}_{1 \mathrm{c}}$ $(R=-0.15, p=0.2906)$.

In children with chronic diseases sAF values were higher than in healthy children (Table IV). Participants taking medication did not differ from participants not taking any medication in respect to sAF values (Table V).

\section{Discussion}

This study provides data on SAF values in children with normal $\mathrm{HbA}_{1 \mathrm{c}}$ concentration, i.e. without dysglycaemia, and to our knowledge is the first one presenting data on SAF values in the Polish paediatric population. The sAF values for our study group were higher than in the Dutch control group in the van der Heyden study (mean [SD] of SAF in our study group 1.22 [0.22] AU - 
Table III. Comparison of tested parameters by gender. $P$ value for Mann-Witney test

\begin{tabular}{|c|c|c|c|c|c|c|c|c|c|c|c|}
\hline \multirow[t]{2}{*}{ Characteristics } & \multicolumn{5}{|c|}{ Girls $(n=41)$} & \multicolumn{6}{|c|}{ Boys $(n=45)$} \\
\hline & Median & $\begin{array}{l}25^{\text {th }} \\
\text { centile }\end{array}$ & $\begin{array}{l}75^{\text {th }} \\
\text { centile }\end{array}$ & Min & Max & Median & $\begin{array}{l}25^{\text {th }} \\
\text { centile }\end{array}$ & $\begin{array}{l}75^{\text {th }} \\
\text { centile }\end{array}$ & Min & Max & $p$ value \\
\hline Age [years] & 11.91 & 8.61 & 14.62 & 2.24 & 17.99 & 11.00 & 6.43 & 13.94 & 3.04 & 16.96 & 0.4364 \\
\hline BMI SDS & 0.04 & -0.24 & 0.72 & -3.55 & 2.29 & 0.05 & -0.36 & 0.79 & -2.04 & 2.09 & 0.9660 \\
\hline $\mathrm{HbA}_{1 \mathrm{c}}[\%]$ & 5.10 & 4.90 & 5.20 & 3.50 & 5.60 & 5.10 & 4.90 & 5.25 & 4.30 & 5.60 & 0.8558 \\
\hline $\begin{array}{l}\mathrm{HbA}_{1 \mathrm{c}} \\
{[\mathrm{mmol} / \mathrm{mol}]}\end{array}$ & 32 & 30 & 33 & 15 & 38 & 32 & 30 & 34 & 23 & 38 & 0.8558 \\
\hline sAF [AU] & 1.20 & 1.06 & 1.26 & 0.93 & 1.76 & 1.20 & 1.06 & 1.30 & 0.90 & 2.50 & 0.4797 \\
\hline
\end{tabular}

BMI-SDS - standard deviation score of $\mathrm{BMI} \mathrm{HbA}_{1 \mathrm{c}}$ - glycated hemoglobin $\mathrm{A}_{1 \mathrm{c}}$; sAF - skin autofluorescence expressed in arbitrary units [AU]

Table IV. Characteristics of participants with and without chronic conditions. $P$ value for Mann-Whitney test

\begin{tabular}{|c|c|c|c|c|c|c|c|c|c|c|c|}
\hline \multirow[t]{2}{*}{ Characteristics } & \multicolumn{5}{|c|}{ Participants with chronic conditions $(n=51)$} & \multicolumn{6}{|c|}{ Participants without chronic conditions $(n=35)$} \\
\hline & Median & $\begin{array}{l}25^{\text {th }} \\
\text { centile }\end{array}$ & $\begin{array}{l}75^{\text {th }} \\
\text { centile }\end{array}$ & Min & Max & Median & $\begin{array}{l}25^{\text {th }} \\
\text { centile }\end{array}$ & $\begin{array}{l}75^{\text {th }} \\
\text { centile }\end{array}$ & Min & Max & $p$ value \\
\hline Age [years] & 11.88 & 8.31 & 14.23 & 3.04 & 17.99 & 11.00 & 5.62 & 14.62 & 2.24 & 16.56 & 0.4710 \\
\hline BMI SDS & -0.01 & -0.36 & 0.62 & -2.04 & 2.09 & 0.13 & -0.21 & 0.85 & -3.55 & 2.29 & 0.5025 \\
\hline $\mathrm{HbA}_{1 \mathrm{c}}[\%]$ & 5.00 & 4.80 & 5.20 & 3.50 & 5.60 & 5.20 & 5.00 & 5.30 & 4.30 & 5.60 & 0.0133 \\
\hline $\begin{array}{l}\mathrm{HbA}_{1 \mathrm{c}} \\
{[\mathrm{mmol} / \mathrm{mol}]}\end{array}$ & 31 & 29 & 33 & 15 & 38 & 33 & 31 & 34 & 23 & 38 & 0.0133 \\
\hline sAF [AU] & 1.23 & 1.10 & 1.40 & 0.90 & 2.50 & 1.16 & 1.06 & 1.26 & 0.90 & 1.60 & 0.0272 \\
\hline
\end{tabular}

Table V. Characteristics of participants taking medication and participants not taking any medication. $P$ value for Mann-Whitney test

\begin{tabular}{|c|c|c|c|c|c|c|c|c|c|c|c|}
\hline \multirow[t]{2}{*}{ Characteristics } & \multicolumn{5}{|c|}{ Participants taking medication $(n=26)$} & \multicolumn{6}{|c|}{ Participants not taking medication $(n=60)$} \\
\hline & Median & $\begin{array}{l}25^{\text {th }} \\
\text { centile }\end{array}$ & $\begin{array}{l}75^{\text {th }} \\
\text { centile }\end{array}$ & Min & Max & Median & $\begin{array}{l}25^{\text {th }} \\
\text { centile }\end{array}$ & $\begin{array}{l}75^{\text {th }} \\
\text { centile }\end{array}$ & Min & Max & $p$ value \\
\hline Age [years] & 12.96 & 8.61 & 14.23 & 5.24 & 17.99 & 10.90 & 6.90 & 14.28 & 2.24 & 17.00 & 0.2835 \\
\hline BMI SDS & 0.05 & -0.22 & 0.63 & -2.04 & 1.45 & 0.04 & -0.36 & 0.74 & -3.55 & 2.29 & 0.8669 \\
\hline $\mathrm{HbA}_{1 \mathrm{c}}[\%]$ & 5.00 & 4.80 & 5.20 & 4.50 & 5.60 & 5.10 & 4.90 & 5.25 & 3.50 & 5.60 & 0.1925 \\
\hline $\begin{array}{l}\mathrm{HbA}_{1 \mathrm{c}} \\
{[\mathrm{mmol} / \mathrm{mol}]}\end{array}$ & 31 & 29 & 33 & 26 & 38 & 32 & 30 & 34 & 15 & 38 & 0.1925 \\
\hline $\mathrm{SAF}[\mathrm{AU}]$ & 1.23 & 1.10 & 1.33 & 1.03 & 1.76 & 1.20 & 1.06 & 1.26 & 0.90 & 2.50 & 0.0844 \\
\hline
\end{tabular}




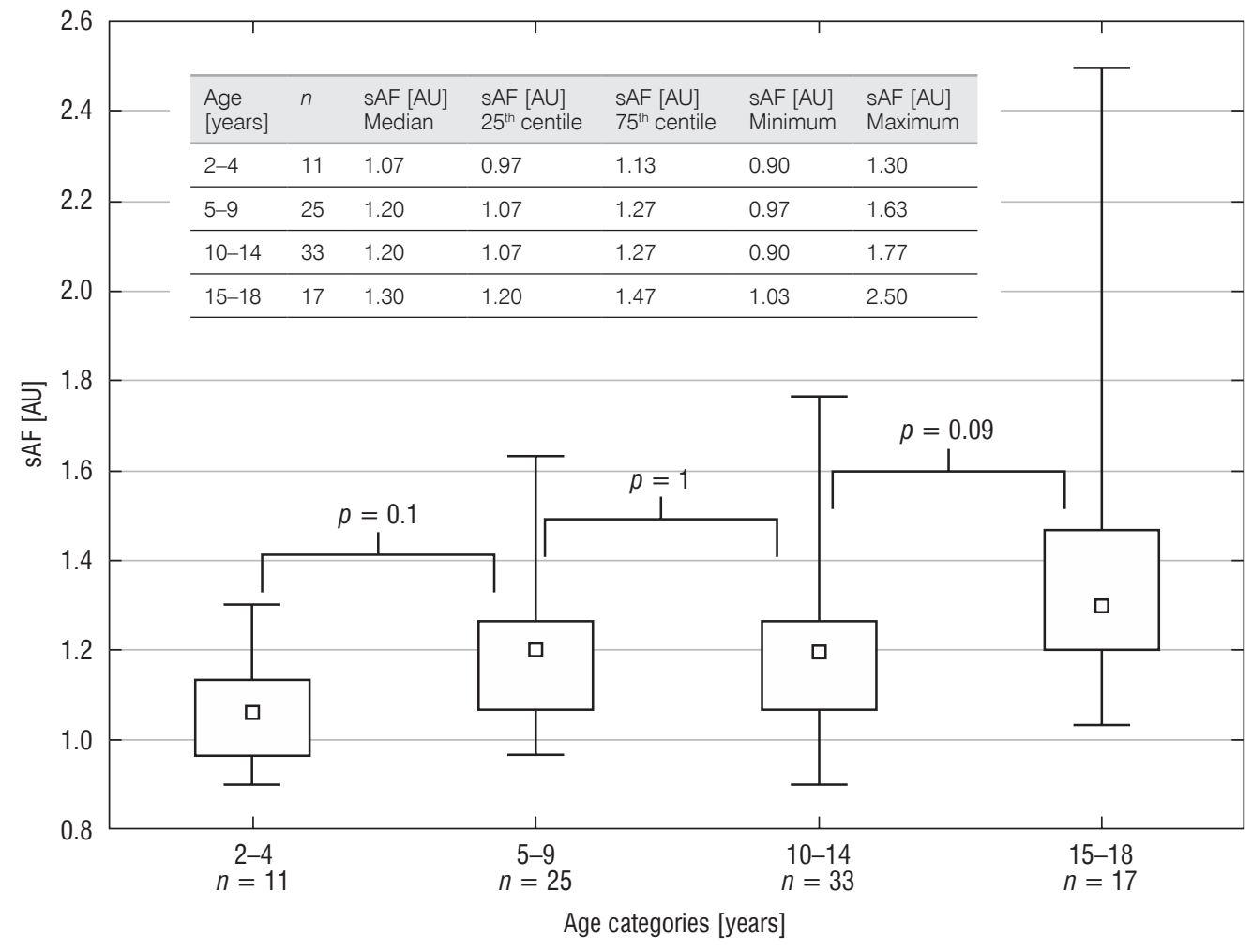

- Median $\square$ 25-75\% I Min-Max

Figure 1. Values of skin autofluorescence (SAF) by age category for the total study group. Boxes represent median values, whiskers represent $25^{\text {th }}$ and $75^{\text {th }}$ centile of SAF values. Age groups were compared with Kruskal-Wallis test, $p=0.017$. Post-hoc comparisons not shown in the figure: age group $2-4$ years vs. $10-14$ years $p=0.17$, age group $2-4$ years vs. $15-18$ years $p=0.0007$; age group $5-9$ years vs. $15-18$ years $p=0.03$

data not shown in Results section, vs. SAF 1.14 [0.14] AU, respectively), even though our study group was younger (median age 11.4 [25-75\%: 8.0-14.2] years vs. 14.4 [25-75\%: 13-15.4] years, respectively) [20]. This may be a consequence of inclusion of participants with chronic conditions into our study or may be due to between-countries differences in SAF shown by Klenovics et al. [6]. The median SAF in our group (1.20 [25-75\%: 1.06-1.30]) was lower than in the Dutch children with type 1 diabetes (T1D) studied by Heyden et al. (median SAF 1.40 [25-75\%: 1.23-1.54]) [20] and by Banser et al. (mean sAF value in children with T1D was $1.33 \pm 0.36 \mathrm{AU}$ ) [21].

We found a positive correlation between SAF and age. AGEs accumulation increases with age, and an increase in SAF with age was also confirmed in previous studies including healthy participants of different ages and in patients with type 2 diabetes (T2D) $[5,6,22]$. Interestingly, we observed stable sAF values between ages 5-9 years and 10-14 years and an increase between the age categories 10-14 years and 15-18 years (Figure 1). Such an SAF-age distribution, with faster increase in the older adolescents compared to younger age groups, was also observed by von der Heyden for patients with diabetes and for children and adolescents without diabetes [20]. Acceleration of the sAF increase with age in older adolescents may be related to exposition to less healthy environments (e.g. smoking or unhealthy nutrition), because it was shown that not only smoking but also a "western" diet increases sAF values [6, 23].

We did not find a difference in SAF values between the sexes, which is contrary to several observations in adult subjects. Only Koetsier et al. did not confirm higher sAF values in women in their non-smoker subgroup of a cohort without diabetes [5]. Higher SAF in female subjects than in male subjects was found in adult populations both without and with diabetes [5, 6, 22]. Lutgers et al. showed that the sex difference in SAF is lost at an older age, and they attributed the sex difference in SAF to higher estrogen concentration in premenopausal women [22]. Because our population was young (median age 11.4 years) and most of the studied girls were before or at early stages of puberty, such an age distribution could blunt the sex effect on SAF in our study group. Another cause may be that SAF measurement is highly sensitive to skin care products [24]. 
Because many women, but not very young girls, use emollients and other skin care products more frequently than male subjects, this could affect sAF measurements in some studied adult populations, which is less probable in a paediatric population, like ours. Data on sex differences in SAF in paediatric populations come from studies that included patients with T1D, and show that such a difference was significant in a mainly teenage population (mean age $13.2 \pm 3.8$ years) [25], while in a younger paediatric population (mean age $12.2 \pm 3.8$ years) no difference between girls and boys was found [21].

We did not find a significant correlation between SAF and BMI-SDS. In adults it was shown that SAF was higher in persons with central obesity compared to non-obese, while in children with diabetes and their healthy siblings a correlation between SAF and BMI was not found [26, 27]. Because only two participants of our study had BMI-SDS $>2$ SDS (i.e. were obese) the effect of BMI might not be revealed or perhaps just young age protects children and adolescents from disclosing the effect of BMI on SAF values because time of exposition is crucial in AGEs accumulation in skin collagen.

In children and adolescents with diabetes a positive correlation between SAF and $\mathrm{HbA}_{1 \mathrm{c}}$ level at the time of SAF measurement was observed in previous studies [21, 25, 26, 28]. Studies analysing the relationship between $\mathrm{HbA}_{1 \mathrm{c}}$ and $\mathrm{SAF}$ in subjects without diabetes are lacking. In the present study, in contrast to reports including young subjects with diabetes, $\mathrm{HbA}_{1 \mathrm{c}}$ levels did not affect sAF values. This may be because blood glucose levels in persons without dysglycaemia rarely reach the concentrations necessary for initiation of excessive advanced glycation, and within such low ranges of AGEs content in the skin their concentration is not evidently proportional to $\mathrm{HbA}_{1 \mathrm{c}}$ levels. Moreover non-glycaemic factors determining glycation of haemoglobin and accumulation of AGEs in skin collagen may be different (e.g. because haemoglobin is located in the intracellular compartment - in erythrocytes - and collagen is located extracellularly), and at normal glucose levels such glucose-independent factors might influence $\mathrm{HbA}_{1 \mathrm{c}}$ formation and AGEs accumulation in skin in such a way that their concentration changes in an incompatible or discordant manner. In our study group $\mathrm{HbA}_{1 \mathrm{c}}$ levels were slightly higher in participants without chronic conditions compared to participants with chronic conditions. However, because all $\mathrm{HbA}_{1 \mathrm{c}}$ values were within the reference range, in our opinion it was just a coincidence that cannot be attributed to any clinical factors.

We found higher sAF values in the subgroup with chronic conditions compared to the subgroup of healthy participants. None of the subjects had any diseases known to affect the sAF measurement (e.g. diabetes, kidney failure, clinically overt cardiovascular disease) [8-12]. So far, reports concerning other chronic diseases and their clinical course in the context of sAF values have been sparse. A large proportion of our subjects had allergies. Although there have been very few reports that can provide a thorough insight on the impact of glycation in allergies, a role of RAGEs in the induction of some pathogenic processes in asthma has been shown in animal models [29]. It was also reported that Maillard reaction products present in food may alter immunoreactivity towards food proteins, enhance the immune response by selective interaction with APCs carrying receptors for AGEs, and promote T-cell differentiation into Th2 cells producing interleukins responsible for the initiation of lgE antibody production [30]. These observations indicate that there may be an association between allergic disorders and AGEs accumulation in the body; however, we did not find any studies that specifically assessed SAF in patients with allergies. Increased polymorphism of AGE receptor (RAGE) and higher oxidative stress levels were found in women with Hashimoto's thyroiditis compared to healthy women, and in another study it was shown that patients with T2D and hypothyroidism presented higher levels of AGEs than those with just T2D [31, 32]. Interestingly, AGEs accumulation in patients with T1D and celiac disease was also studied, and it was shown that in adult persons with T1D celiac disease did not increase AGEs levels in blood [33]. The above results indicate that certain autoimmune diseases may affect the body's AGEs content, and others do not. Because in our study children with autoimmune thyroid diseases were among the participants with chronic conditions, which, as a total subgroup, presented higher sAF than healthy children, we suggest that the relation between thyroid disorders and SAF values in the paediatric population deserves further research.

The highest SAF value was detected in a boy with a history of acute pancreatitis and laboratory features of hepatitis at the time of examination. In this subject we can suspect that oxidative stress related to persistent inflammation could influence AGEs production and affect SAF measurement. The second highest SAF value in our study group was detected in a girl from the subgroup with diseases of the blood. She had von Willebrand disease and was taking tranexamic acid and etamsylate. This patient's medication might have affected SAF readings; etamsylate has native fluorescence properties [34].

Higher sAF values in the group of children with chronic diseases compared to healthy children, along with normal $\mathrm{HbA}_{1 \mathrm{c}}$ concentrations in both groups, indicate that diseases occurring in the studied population (allergic disorders, diseases of the blood, disorders of the digestive system and thyroid, epilepsy, and others) might have an influence on sAF readings. However, because the difference in SAF between these subgroups was slight, larger groups of patients with different disorders should be studied to determine whether and which diseases influence the AGEs content or affect performance of sAF measurement, and to determine which factors related to these diseases are responsible for such effects (e.g. pathogenetic mechanisms or medication).

The strengths of our study are that we tested $\mathrm{HbA}_{1 \mathrm{c}}$ to exclude participants with dysglycaemia, and that we compared SAF in healthy children to participants with chronic conditions that were not previously analysed in the context of SAF assessment. Our data let us yield quasi-reference sAF values for different age groups of children with normal $\mathrm{HbA}_{1 \mathrm{c}}$ levels (Figure 1). However, due to the limitation of the small size of subgroups it did not provide sufficient information to present such values for homogenous subgroups of children without any diseases and with particular chronic conditions. Another limitation was 
Jankowska M., Bobeff K., Baranowska-Jaźwiecka A., Mianowska M., Lubnauer A., Michalak A., Młynarski W., Szadkowska A., Mianowska B.

that we did not analyse environmental factors that might affect AGEs levels, i.e. the participants diet, physical activity, and their smoking status.

\section{Conclusions}

To our knowledge, we present first data on sAF values in Polish children without diabetes. In order to determine whether

\section{References}

1. Dyer DG, Dunn JA, Thorpe SR, et al. Accumulation of Maillard reaction products in skin collagen in diabetes and aging. J Clin Invest 1993; 91: 2463-2469. doi: 10.1172/JCl116481

2. Warwas M, Piwowar A, Kopiec G. Zaawansowane produkty glikacji (AGE) w organizmie - powstawanie, losy, interakcja z receptorami i jej następstwa. Farm Pol 2010; 66: 585-590.

3. Hu H, Jiang H, Zhu L, et al. Accumulation of Advanced Glycation Endproducts and Subclinical Inflammation in Deep Tissues of Adult Patients With and Without Diabetes. Can J Diabetes 2018; 42: 525-532.e4. doi: 10.1016/j.jcjd.2018.01.003

4. Meerwaldt R, Graaff R, Oomen PHN, et al. Simple non-invasive assessment of advanced glycation endproduct accumulation. Diabetologia 2004; 47: 1324-1330. doi: 10.1007/s00125-004-1451-2

5. Koetsier M, Lutgers HL, de Jonge $C$, et al. Reference values of skin autofluorescence. Diabetes Technol Ther 2010; 12: 399-403. doi: 10.1089/dia.2009.0113

6. Simon Klenovics K, Kollárová R, Hodosy J, et al. Reference values of skin autofluorescence as an estimation of tissue accumulation of advanced glycation end products in a general Slovak population. Diabet Med 2014; 31: 581-585. doi: 10.1111/dme.12326

7. Drenth H, Zuidema SU, Krijnen WP, et al. Advanced Glycation End Products Are Associated With Physical Activity and Physical Functioning in the Older Population. J Gerontol A Biol Sci Med Sci 2018; 73: 1545-1551. doi: 10.1093/gerona/gly108

8. Cavero-Redondo I, Soriano-Cano A, Álvarez-Bueno C, et al. Skin Autofluorescence-Indicated Advanced Glycation End Products as Predictors of Cardiovascular and All-Cause Mortality in High-Risk Subjects: A Systematic Review and Meta-analysis. J Am Heart Assoc 2018; 7: p. e009833. doi: 10.1161/JAHA.118.009833

9. Yamagishi S, Fukami K, Matsui T. Evaluation of tissue accumulation levels of advanced glycation end products by skin autofluorescence: A novel marker of vascular complications in high-risk patients for cardiovascular disease. Int J Cardiol 2015; 185: 263-268. doi: 10.1016/j.jijcard.2015.03.167

10. Cleary PA, Braffett BH, Orchard T, et al. Clinical and technical factors associated with skin intrinsic fluorescence in subjects with type 1 diabetes from the Diabetes Control and Complications Trial/ Epidemiology of Diabetes Interventions and Complications Study. Diabetes Technol Ther 2013; 15: 466-474.

11. Orchard TJ, Lyons TJ, Cleary PA, et al. The association of skin intrinsic fluorescence with type 1 diabetes complications in the DCCT/ and which diseases affect the measurement of AGEs content in the skin, in future research it is important to take into account both medical history and concurrent treatment, as well as physical activity, dietary habits, personal and environmental smoking status. Larger, homogenous populations of different ages should be studied to provide reference values for children without diabetes, which will permit wider use of SAF measurement in the assessment of cardiovascular risk in the Polish paediatric population.

EDIC study. Diabetes Care 2013; 36: 3146-3153. doi: 10.2337/ dc12-2661

12. McIntyre NJ, Fluck RJ, McIntyre CW, et al. Skin autofluorescence and the association with renal and cardiovascular risk factors in chronic kidney disease stage 3. Clin J Am Soc Nephrol 2011; 6: 2356-2563. doi: 10.2215/CJN.02420311

13. Drenth H, Zuidema SU, Krijnen WP, et al. Advanced Glycation EndProducts Are Associated With the Presence and Severity of Paratonia in Early Stage Alzheimer Disease. J Am Med Dir Assoc 2017; 18: 636.e7-636.e12. doi: 10.1016/j.jamda.2017.04.004

14. Mulder DJ, Water TV, Lutgers HL, et al. Skin autofluorescence, a novel marker for glycemic and oxidative stress-derived advanced glycation endproducts: an overview of current clinical studies, evidence, and limitations. Diabetes Technol Ther 2006; 8: 523-535. doi: 10.1089/dia.2006.8.523

15. van Waateringe RP, Fokkens BT, Slagter SN, et al. Skin autofluorescence predicts incident type 2 diabetes, cardiovascular disease and mortality in the general population. Diabetologia 2019; 62: 269-280. doi: 10.1007/s00125-018-4769-x

16. Blanc-Bisson C, Velayoudom-Cephise FL, Cougnard-Gregoire A, et al. Skin autofluorescence predicts major adverse cardiovascular events in patients with type 1 diabetes: a 7-year follow-up study. Cardiovasc Diabetol 2018; 17: 82. doi: 10.1186/s12933018-0718-8

17. Lutgers HL, Gerrits EG, Graaff R, et al. Skin autofluorescence provides additional information to the UK Prospective Diabetes Study (UKPDS) risk score for the estimation of cardiovascular prognosis in type 2 diabetes mellitus. Diabetologia 2009; 52: 789-797. doi: 10.1007/s00125-009-1308-9

18. Fokkens BT, van Waateringe RP, Mulder DJ, et al. Skin autofluorescence improves the Finnish Diabetes Risk Score in the detection of diabetes in a large population-based cohort: The LifeLines Cohort Study. Diabetes Metab 2018; 44: 424-430. doi: 10.1016/j. diabet.2017.09.002

19. American Diabetes Association. 2. Classification and Diagnosis of Diabetes. Diabetes Care 2019; 42 Suppl 1: S13-S28. doi: 10.2337/ dc19-S002

20. van der Heyden JC, Birnie E, Mul D, et al. Increased skin autofluorescence of children and adolescents with type 1 diabetes despite a well-controlled HbA1c: results from a cohort study. BMC Endocr Disord 2016; 16: 49. doi: 10.1186/s12902-016-0129-3

21. Banser A, Naafs JC, Hoorweg-Nijman JJ, et al. Advanced glycation end products, measured in skin, vs. HbA1c in children with 
type 1 diabetes mellitus. Pediatr Diabetes 2016; 17: 426-432. doi: 10.1111/pedi.12311

22. Lutgers HL, Graaff R, Links TP, et al. Skin autofluorescence as a noninvasive marker of vascular damage in patients with type 2 diabetes. Diabetes Care 2006; 29: 2654-2659. doi: 10.2337/dc05-2173

23. Hjerrild JN, Wobbe A, Stausholm MB, et al. Effects of Long-Term Physical Activity and Diet on Skin Glycation and Achilles Tendon Structure. Nutrients 2019; 11: pii: E1409. doi: 10.3390/nu11061409

24. Noordzij MJ, Lefrandt JD, Graaff R, et al. Dermal factors influencing measurement of skin autofluorescence. Diabetes Technol Ther 2011; 13: 165-170. doi: 10.1089/dia.2010.0123

25. Felipe DL, Hempe JM, Liu S, et al. Skin intrinsic fluorescence is associated with hemoglobin $A(1 \mathrm{c})$ and hemoglobin glycation index but not mean blood glucose in children with type 1 diabetes. Diabetes Care 2011; 34: 1816-1820. doi: 10.2337/dc11-0049

26. Barat P, Cammas B, Lacoste A, et al. Advanced glycation end products in children with type 1 diabetes: family matters? Diabetes Care 2012; 35: p. e1. doi: 10.2337/dc11-1398

27. den Engelsen C, van den Donk M, Gorter KJ, et al. Advanced glycation end products measured by skin autofluorescence in a population with central obesity. Dermatoendocrinol 2012; 4: 33-38. doi: 10.4161/derm.17999

28. Cho YH, Craig ME, Januszewski AS, et al. Higher skin autofluorescence in young people with Type 1 diabetes and microvascular complications. Diabet Med 2017; 34: 543-550. doi: 10.1111/ dme.13280
29. Perkins TN, Oczypok EA, Dutz RE, et al. The receptor for advanced glycation end products is a critical mediator of type 2 cytokine signaling in the lungs. J Allergy Clin Immunol 2019; 144: 796-808.e12. doi: 10.1016/j.jaci.2019.03.019

30. Teodorowicz M, van Neerven J, Savelkoul H. Food Processing: The Influence of the Maillard Reaction on Immunogenicity and Allergenicity of Food Proteins. Nutrients 2017; 9: pii: E835. doi: 10.3390/ nu9080835

31. Giannakou M, Saltiki K, Mantzou E, et al. RAGE polymorphisms and oxidative stress levels in Hashimoto's thyroiditis. Eur J Clin Invest 2017; 47: 341-347.doi: 10.1111/eci.12739

32. Chen XJ, Gong XH, Jie JP, et al. Receptor for advanced glycation end products reveals a mechanism regulating thyroid hormone secretion through the SIRT1/Nrf2 pathway. J Cell Biochem 2019; 120 : 4582-4598. doi: 10.1002/jcb.27747

33. Bakker SF, Tushuizen ME, Gözütok E, et al. Advanced glycation end products (AGEs) and the soluble receptor for AGE (SRAGE) in patients with type 1 diabetes and coeliac disease. Nutr Metab Cardiovasc Dis 2015; 25: 230-235. doi: 10.1016/j.numecd.2014.10.009

34. Belal F, El-Brashy A, El-Enany N, et al. Conventional and first derivative synchronous fluorometric determination of ethamsylate in pharmaceutical preparations and biological fluids. Application to stability studies. J Fluoresc 2011; 21: 1371-1384. doi: 10.1007/ s10895-010-0819-6 